International Journal of Business, Economics and Management

2019 Vol. 6, No. 2, pp. 99-110

$\operatorname{ISSN}(e): 2312-0916$

$\operatorname{ISSN}(p): 2312-5772$

DOI: $10.18488 /$ journal.62.2019.62.99.110

(C) 2019 Conscientia Beam. All Rights Reserved.

check for
updates

\title{
DECISION-MAKING ON WORKING CAPITAL MANAGEMENT, BASED ON INDUSTRY DIFFERENCES
}

\author{
Haritini Tsangari ${ }^{1}$ \\ 'Department of Economics and Finance, School of Business, University of \\ Nicosia, Nicosia, Cyprus \\ Email:tsangari.h@unic.ac.cy
}

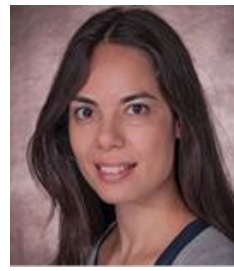

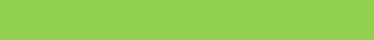

ABSTRACT

Article History

Received: 15 November 2018 Revised: 31 December 2018 Accepted: 5 February 2019 Published: 9 April 2019

\section{Keywords}

Working capital management Gross operating profit Cash conversion cycle Industry differentiation Consumer goods sector Industrials sector

Consumer services.

JEL Classification: C12; C23; G30; G31; G32

The effect of working capital components on profitability has conflicting empirical evidence, which is mostly data-driven. This paper aims to provide additional insight to this end, especially focusing on the neglected aspect of industry differentiation. The analysis implements a panel regression methodology on a dataset of 300 observations from firms in Cyprus, adjusting for control variables and considering industry differences. Overall, the present study illustrates that industry differences warrant indepth examination for decision-making regarding working capital management policies. The findings show that the cash conversion cycle and its components have an effect on profitability, but the sign and level of significance vary according to the industry sector: results in the merged sample differ from the results by industry sector. For example, the cash conversion cycle has a positive effect on the consumer goods sector and a negative effect in the industrials sector. Additionally, management of creditors and suppliers is as important as the management of debtors, especially for consumer goods and industrials. Managers should aim for the optimal level of the working capital components, while simultaneously adjusting their strategies based on their industry sector, to boost firm profitability.
\end{abstract}

Contribution/Originality: This study contributes to the existing literature regarding the effect of working capital management on profitability. The paper's primary contribution is finding that the sign and level of the effect of the cash conversion cycle and its components on profitability vary according to the industry sector, which can thus adjust decision-making.

\section{INTRODUCTION}

Decision-making on working capital management has important implications on corporate value and profitability and is considered to be a critical component in the success or failure of a business. The importance of balancing a company's liquidity and profitability has been widely examined, where working capital management has been shown to directly impact that balance (Lazaridis and Tryfonidis, 2006; Narware, 2008; Ramachandran and Janakiraman, 2009; Zariyawati et al., 2009; Bagchi and Khamrui, 2012). On one hand, attempts to maximise profitability (overtrading) can result to liquidity decreases, making it difficult for the company to meet its everyday obligations and additionally increase its risk of bankruptcy (Raheman and Nasr, 2007; Eda and Mehmet, 2009; Mathuva, 2010). On the other hand, a working capital management policy that favors liquidity and over-invests in 
current assets (over-capitalization) might consequently inversely influence a company's profitability (Eljelly, 2004; Dong and Su, 2010). It is therefore expected that bad decision-making on working capital management may result in the declining performance of a company and have a negative impact on profitability, which may consequently negatively impact shareholders' wealth (García-Teruel and Martinez-Solano, 2007; Dong and Su, 2010; Gill et al., 2010).

Managers spend a considerable amount of time on planning and controlling working capital, a process that can be very time-consuming (Raheman and Nasr, 2007; Mathuva, 2010). The need to assist in this process has resulted in a more extensive study of the interrelationship between working capital and profitability. Data from many countries and varying economies have provided empirical evidence on this relation, which is often conflicting.

The current article aims to have a three-fold contribution. First, it provides further insight into the effect of working capital and its components on profitability. Second, it uses data from mostly small and medium enterprises (SMEs) in the economy of Cyprus, providing lessons from a pre-crisis period to be used in a post-crisis period, thus omitting the dysfunctional crisis period. Third, and most important, it focuses on industry differences and shows their significance. Industry effects on the interrelation between working capital management and profitability have received limited attention in the literature. Very few studies have considered them in their models, but they did not go into depth regarding the nature of industry differences (e.g., Mathuva (2010)).

\section{LITERATURE REVIEW}

Working capital management has a significant impact on a company's profitability (Deloof, 2003; Lazaridis and Tryfonidis, 2006; Gill et al., 2010; Mathuva, 2010; Kieschnick et al., 2013). Working capital is known to be best described by the cash conversion cycle, which indicates the time gap between purchase of goods and collection of sales or how long a firm can carry on if it was to stop its operation (García-Teruel and Martinez-Solano, 2007; Raheman and Nasr, 2007; Zariyawati et al., 2009). Thus, numerous studies have used the cash conversion cycle and its components, namely days accounts payables, days accounts receivables and inventory holding period, as the explanatory variables for the variation of profitability (Porta et al., 1998; Lazaridis and Tryfonidis, 2006; Dong and Su, 2010; Mohamad and Saad, 2010; Bieniasz and Gołás, 2011; Abuzayed, 2012; Obeidat and Jawabri, 2016).

Conflicting empirical evidence exists regarding the relationship between the cash conversion cycle and profitability, which is usually data-driven. Many studies have shown a negative relation (Deloof, 2003; Lazaridis and Tryfonidis, 2006; García-Teruel and Martinez-Solano, 2007; Raheman and Nasr, 2007; Ramachandran and Janakiraman, 2009; Zariyawati et al., 2009; Dong and Su, 2010; Bagchi and Khamrui, 2012). On the contrary, Gill et al. (2010) resulted in a positive relationship between gross operating profitability and the cash conversion cycle, while other authors similarly mention that extension of the cash conversion cycle can lead to increased sales and higher profits (Mathuva, 2010). It is noteworthy that conflicting results have been even found using the same sample but different testing methodologies: Padachi (2006) found a positive, but not significant relationship between the cash conversion cycle and profitability with a fixed effects model, but a negative relation when using a pooled OLS approach.

Similarly, there is no consensus in the literature on the effect of the components of the cash conversion cycle on profitability. Regarding "days accounts payables", the results of several studies show an inverse relationship with profitability (Porta et al., 1998; Deloof, 2003; Lazaridis and Tryfonidis, 2006; García-Teruel and Martinez-Solano, 2007; Raheman and Nasr, 2007; Wasiuzzaman, 2015). Conversely, many studies resulted in a positive relationship between creditors' payment period and profitability, indicating that by extending payment to creditors profitability will rise (Narware, 2008; Ramachandran and Janakiraman, 2009; Dong and Su, 2010; Gill et al., 2010; Mathuva, 2010).

"Days accounts receivables" can be defined as the number of days from the moment of sale until receipt of payment (e.g., Bieniasz and Gołaś (2011)). According to theory, a policy for determining the optimal amount of 
account receivables has to consider three pillars: 1) the trade-off between the securing of sales and profits and the amount of opportunity cost and administrative costs of the increasing account receivables; 2) the level of risk the firm is prepared to take when extending credit to a customer, because the customer could default when payment is due, and 3) the investment in debt collection management (Berry and Jarvis, 2006). A generous trade policy can lead to higher sales, since it offers customers incentives to buy at periods of lower demand, while it additionally reduces transaction costs and offers the buyer a period to check the order's quantity and quality prior to payment (Deloof, 2003; Lazaridis and Tryfonidis, 2006; García-Teruel and Martinez-Solano, 2007; Gill et al., 2010). A generous trade policy can enhance the trust and strengthen the long term relationships with existing customers, as well as help attract new customers since it is an inexpensive and flexible source of financing (García-Teruel and MartinezSolano, 2007; Gill et al., 2010). On the other hand, uncollected accounts receivables lead to cash inflow problems if not planned and handled correctly. Lacking payment from their customers, managers would have to pay their own suppliers from reserves or other sources of external finance, which, in turn, would cause the financing costs to increase (Dong and Su, 2010). And, although credit sales increase the sales volume of the company, this may lead to an increase in "bad debts" (Bhattacharya, 2003). Increased average collection period generally reflects poor collection efforts, delays in customer payments and customers financial distress (Bernstein and Wild, 1998). Therefore, it is essential for firms to implement a suitable collection policy. Most studies agree on a negative relation between days accounts receivables and profitability, implying that the shorter the period the firm allows credit to its customers, the higher its profitability (Deloof, 2003; Lazaridis and Tryfonidis, 2006; Raheman and Nasr, 2007; Zariyawati et al., 2009; Mathuva, 2010). Some exceptions are, however, found, such as Muscettola (2014), Narware (2008), Ramachandran and Janakiraman (2009) and Sharma and Kumar (2011).

Contradictory findings similarly exist in the relationship between the "inventory holding period" and profitability. The inventory holding period can be defined as the time taken to convert inventory held in the firm into sales (e.g., Mathuva (2010)). Many studies indicate that the shorter the inventory is kept unsold, the more working capital is available for reinvestment within the firm, and thus the higher the profitability (Deloof, 2003; Lazaridis and Tryfonidis, 2006; Raheman and Nasr, 2007; Ramachandran and Janakiraman, 2009; Zariyawati et al., 2009). The results of Narware (2008) and Mathuva (2010) contradicted these findings, illustrating a positive relationship between inventory holding period and profitability. Very scarce evidence exists regarding industry effects on the relationship between working capital management and profitability. One of the few studies that actually found a significant industry effect was Zariyawati et al. (2009) but the nature of differences among industry sectors was not further examined in their study. Mathuva (2010) similarly mentioned the inclusion of an industry variable in his models, but its level of significance was never discussed or reported in the tables with the regression results, whereas a study by Oruc and Sen (2009) did not find significant differences within industry sectors.

\section{THEORETICAL FRAMEWORK AND METHODOLOGY}

\subsection{Sample Data}

Cyprus was chosen for the current study because although it is a country that presents international interest due to its economic history and current turbulence it lacks empirical evidence on firm management.

Cyprus is a member of the European Union and belongs to the Eurozone. It adopted the euro in 2008. It has an open, free-market, services-based economy with some light manufacturing. Despite its small size Cyprus has had a record of successful economic performance, reflected in strong growth, full employment conditions and relative stability. The underdeveloped agrarian economy moved away from the primary and secondary sectors and was transformed into a modern economy, with dynamic services, industrial and agricultural sectors and an advanced physical and social infrastructure (Ministry of Finance, 2011). The economy of Cyprus was classified by the World Bank as a high-income economy and was included by the International Monetary Fund in its list of advanced economies in 2001 (International Monetary Fund, 2001; World Bank, 2001). 
The fiscal consolidation programme of the government of the Republic of Cyprus, for the years, 2004-2008 aimed at improving the functioning of the product, capital and labour markets in Cyprus and securing an internationally competitive environment for business and industry (MoF, 2004). Indeed, the years 2004 to 2007 were marked by a very satisfactory economic growth and exceptional revenues, especially brought by the boom in the real estate sector, with an average annual growth rate of $4.1 \%$ in real terms (Tsangari, 2010). Looking at the growth path of services during 2006-2008, the financial sector and business sector were the fastest growing sectors (MoF, 2011).

In 2008, and as a result of the global financial crisis, economic activity in Cyprus was reduced and the average annual growth rate decreased to 3.7\% (Ministry of Labour and Social Insurance, 2008). During 2009, after more than three decades of consistent growth, the Cypriot economy contracted; construction and real estate activities were diminished and capital gains tax receipts and land and survey fees exhibited sharp declines (MoF, 2011; IMF, 2014). The economy contracted by an accumulated 8.2\% between 2009 and 2013. Economic failure became worse during the years 2012-2013. The Cypriot financial crisis, part of the wider Eurozone crisis, reflected the exposure of Cyprus to the global recession and European sovereign debt crisis, in addition to concerns about the state of public finances and spiraling borrowing costs. Today, Cyprus is slowly and robustly emerging out of its economic crisis, it has managed to keep its international comparative advantages and can focus again on its long-term growth strategy (Hardouvelis and Gkionis, 2016).

For the purpose of the study, annual data were collected from the financial statements of all the firms listed in the Cyprus Stock Exchange, for the pre-crisis period of 2004 to 2008 (Cyprus Stock Exchange, 2011). This period was intentionally selected for the analysis, since it was a period which had efficient functioning of the product, capital and labour markets in Cyprus, focusing on an internationally competitive environment for business and industry, continuing the economic success of the years before 2004. The post-crisis years shortly after 2009 could be considered exceptional for Cyprus, while the current period, the years after 2016, could be considered as a transitional period for its economy, or a period of economic recovery. Therefore, the pre-crisis period will provide lessons for the current post-crisis period.

Listed companies were preferred since such companies undergo a mandatory audit and have an incentive on presenting reliable and truthful financial statements and show profits, where present, to attract more investors to buy their shares (Lazaridis and Tryfonidis, 2006; Mathuva, 2010). Electricity and water authorities, banking and financial institutions and insurance companies were excluded from the study, because, due to their type of activity, the calculation of their working capital management is very different (Deloof, 2003; Lazaridis and Tryfonidis, 2006; Raheman and Nasr, 2007; Mathuva, 2010). The total number of listed companies for the period under examination was 123 , which reduced to 88 after excluding the abovementioned companies. Some companies were additionally excluded due to lack of information for a certain period, and others because they were purely service companies that held no inventory. The final sample included sixty firms, resulting in a total of 300 stacked observations for the five years of examination.

\subsection{Methodology}

To examine the interrelationship between profitability and working capital management of companies, the study used a repeated measures design (pooled time-series cross-sectional design), which has many advantages. For example, panel data modelling assumes that firms are heterogeneous and therefore better controls for bias. Moreover, it offers more variability to the study, less collinearity and more degrees of freedom, resulting in the estimates to be more efficient and providing information on the time-ordering of events, thus allowing to control for individual unobserved heterogeneity (García-Teruel and Martinez-Solano, 2007; Mathuva, 2010). 
The statistical methods included descriptive statistics, one-way Analysis of Variance (ANOVA) tests and regression analysis for panel data, namely pooled OLS regression. The dependent variable, chosen as a measure of corporate profitability for the regression analysis, was the Gross Operating Profit (GOP), calculated as:

$$
\text { Gross Operating Profit }=\frac{\text { Sales-Cost of goods sold }}{\text { Total assets }- \text { Financial assets }}
$$

The same variable was used in many such previous studies to measure profitability (Deloof, 2003; Lazaridis and Tryfonidis, 2006; Gill et al., 2010) and GOP was preferred instead of Return on Assets (ROA), Earnings Before Interest and Tax (EBIT) or Earnings before interest, tax, depreciation and amortization (EBITDA) for a number of reasons: using GOP allows to associate operating performance (success or failure) with an operating ratio, and relate this variable with other operating variables like the cash conversion cycle and its components. In addition, using GOP as a measure of profitability excludes the participation of any financial activity from operational activity that may affect overall profitability (Lazaridis and Tryfonidis, 2006; Gill et al., 2010). According to Deloof (2003) when a company has a large number of financial assets on its balance sheet, its operating activities will contribute little to the overall return on assets, thus making it an inappropriate variable in this case, and for this reason financial assets are deducted from total assets in GOP. In fact, a large percentage of the chosen Cypriot companies do have a large number of financial assets, mainly shares in other firms or subsidiaries.

The independent variables in the study were as follows:

Days accounts payables $(\mathrm{AP})=(\text { Accounts Payables } / \text { Cost of Goods Sold })^{*} 365$

Days accounts receivables $(\mathrm{AR})=($ Accounts receivables $/$ Sales $) * 365$

Inventory Holding period (days) $(\mathrm{INV})=($ Inventory $/$ Cost of Goods Sold $) * 365$

Cash conversion cycle $($ days $)(\mathrm{CCC})=$

$=$ Days accounts receivables + Inventory Holding period - Days accounts payables

The control variables of the study included Financial debt ratio ("Debt"), Fixed Financial Asset Ratio ("FFA"), Firm Size ("Size") and Gross Domestic Product growth (\% annual change) ("GDPgr"). Financial debt ratio was calculated by adding short term loans to long term loans, divided by total assets. Fixed financial asset ratio was calculated as "fixed financial assets divided by total assets", whereas firm size was the natural logarithm of sales, in agreement with Deloof (2003), Lazaridis and Tryfonidis (2006), Raheman and Nasr (2007), Ramachandran and Janakiraman (2009), Gill et al. (2010) and Mathuva (2010). All the variables were calculated using balance sheet and income statement values. The inclusion of GDP growth aimed to control for the evolution of the economic cycle, since adverse or favorable economic conditions are reflected in the firm's performance, to control inflationary pressures and also to reflect economic changes in the macroeconomic environment (Mathuva, 2010). GDP was retrieved from CYSTAT for the period 2004-2008 (Republic of Cyprus Ministry of Finance Statistical Service, 2003-2008). Constant market prices were used, instead of current market GDP, since constant price GDP measures, value-added production expressed in a particular year, the base period, in this case, 2005, and thus it is corrected for inflation and deflation and is not driven only from price changes. Finally, "Industry" was also added as a categorical variable in the model, in order to examine industry effects. The sixty companies used in the study (which were mostly SMEs) were divided into four broad industry sectors: consumer goods, industrials, consumer services and technology. Follow-up analyses for industry differences were based on the results regarding the significance of "Industry".

All the statistical analyses were carried out using the Statistical Package for Social Sciences (SPSS, version 23). 


\section{RESULTS}

\subsection{Descriptive Statistics}

Descriptive statistics for the variables of interest appear in Table 1. The results appear for all companies taken as a merged sample, as well as per industry (consumer goods, industrials, consumer services, technology).

As can be seen in Table 1, the mean gross operating profit for all companies during the five-year period was $18 \%$, with a standard deviation of $16 \%$. The one-way Analysis of Variance (ANOVA) test for industry differences indicated that significant differences existed in the profitability among firms in various industries $(\mathrm{F}=7.34$, $\mathrm{p}<0.001)$. A first look at the figures shows that the lowest GOP was for the technology firms $(6 \%)$ and the highest for the consumer goods industry (23\%). The statistical analysis that will follow will shed more light to the profitability differences per industry.

Table-1. Descriptives for the key variables and one-way ANOVA tests for differences between industries.

\begin{tabular}{|c|c|c|c|c|c|c|}
\hline Variable & All industries & $\begin{array}{l}\text { ANOVA test for } \\
\text { industry effect }\end{array}$ & $\begin{array}{l}\text { Consumer } \\
\text { goods }\end{array}$ & Industrials & $\begin{array}{c}\text { Consumer } \\
\text { services }\end{array}$ & Technology \\
\hline & $(\mathrm{N}=300)$ & & $(\mathrm{N}=60)$ & $(\mathrm{N}=80)$ & $(\mathrm{N}=145)$ & $(\mathrm{N}=15)$ \\
\hline & $\begin{array}{c}\text { Mean } \\
(\mathrm{SD})\end{array}$ & $\begin{array}{c}\mathrm{F} \\
\text { (p-value) }\end{array}$ & $\begin{array}{c}\text { Mean } \\
(\mathrm{SD})\end{array}$ & $\begin{array}{c}\text { Mean } \\
(\mathrm{SD})\end{array}$ & $\begin{array}{c}\text { Mean } \\
(\mathrm{SD})\end{array}$ & $\begin{array}{c}\text { Mean } \\
(\mathrm{SD})\end{array}$ \\
\hline GOP & $\begin{array}{c}0.18 \\
(0.16)\end{array}$ & $7.34(<0.001)^{* * *}$ & $\begin{array}{c}0.23 \\
(0.17) \\
\end{array}$ & $\begin{array}{c}0.14 \\
(0.09)\end{array}$ & $\begin{array}{c}0.19 \\
(0.18)\end{array}$ & $\begin{array}{c}0.06 \\
(0.06)\end{array}$ \\
\hline $\mathrm{CCC}$ & $91.48(412.26)$ & $7.36(<0.001)^{* *}$ & $251.49(387.61)$ & $\begin{array}{c}164.20 \\
(153.28) \\
\end{array}$ & $\begin{array}{c}2.51 \\
(450.11) \\
\end{array}$ & $\begin{array}{c}-76.36 \\
(726.69) \\
\end{array}$ \\
\hline $\mathrm{AP}$ & $\begin{array}{c}188.81 \\
(345.91)\end{array}$ & $5.78(0.001)^{* *}$ & $\begin{array}{l}107.33 \\
(52.73)\end{array}$ & $\begin{array}{r}111.46 \\
(70.28) \\
\end{array}$ & $\begin{array}{c}243.28 \\
(435.40)\end{array}$ & $\begin{array}{c}400.68 \\
(651.54)\end{array}$ \\
\hline $\mathrm{AR}$ & $\begin{array}{c}125.99 \\
(187.10) \\
\end{array}$ & $6.36(<0.001)^{* *}$ & $203.27(373.34)$ & $\begin{array}{r}141.22 \\
(88.58) \\
\end{array}$ & $\begin{array}{c}84.17 \\
(79.73) \\
\end{array}$ & $\begin{array}{c}139.88 \\
(73.2) \\
\end{array}$ \\
\hline INV & $\begin{array}{c}154.30 \\
(188.41)\end{array}$ & $\begin{array}{c}0.50 \\
(0.686) \\
\end{array}$ & $155.55(144.82)$ & $\begin{array}{c}134.44 \\
(172.29) \\
\end{array}$ & $\begin{array}{c}161.62 \\
(211.51) \\
\end{array}$ & $\begin{array}{c}184.44 \\
(195.82)\end{array}$ \\
\hline Size & $\begin{array}{l}16.19 \\
(1.39)\end{array}$ & $5.26(0.002)^{* *}$ & $\begin{array}{l}15.79 \\
(1.02)\end{array}$ & $\begin{array}{l}16.45 \\
(0.98)\end{array}$ & $\begin{array}{l}16.31 \\
(1.67)\end{array}$ & $\begin{array}{l}15.28 \\
(1.03)\end{array}$ \\
\hline Debt & $\begin{array}{c}0.27 \\
(0.36)\end{array}$ & $\begin{array}{c}1.88 \\
(0.134)\end{array}$ & $\begin{array}{c}0.17 \\
(0.15)\end{array}$ & $\begin{array}{c}0.30 \\
(0.64)\end{array}$ & $\begin{array}{c}0.29 \\
(0.16)\end{array}$ & $\begin{array}{c}0.23 \\
(0.16)\end{array}$ \\
\hline FFA & $\begin{array}{c}0.08 \\
(0.16) \\
\end{array}$ & $6.45(<0.001)^{* *}$ & $\begin{array}{c}0.06 \\
(0.11) \\
\end{array}$ & $\begin{array}{c}0.10 \\
(0.21) \\
\end{array}$ & $\begin{array}{c}0.07 \\
(0.14) \\
\end{array}$ & $\begin{array}{c}0.25 \\
(0.17) \\
\end{array}$ \\
\hline GDPgr & $\begin{array}{c}4.20 \\
(0.51)\end{array}$ & & & & & \\
\hline
\end{tabular}

The cash conversion cycle for the merged sample of Cyprus companies was on average 91 days, illustrating the time lag between the purchase of goods and actual collection from sales and indicating that on average companies completed approximately four cycles during a year. This statistic was accompanied by a large standard deviation of 412 days, reflecting large variation among companies, which also required controlling for outliers in the regression analyses. The ANOVA test showed significant differences between industries $(\mathrm{p}<0.001)$, with average cash conversion cycles ranging from negative to positive (from -76 days for technology firms to 251 days for firms in the consumer goods industry).

ANOVA results were combined with post hoc Tukey tests, where necessary, for pairwise comparisons for all the variables of interest. The mean creditors' payment period (days accounts payables) for the total sample was 189 days, while these companies received payment for their sales (days accounts receivables) within 126 days on average, with significant differences between industries for both variables $(\mathrm{p}=0.001$ and $\mathrm{p}<0.001$ respectively). More specifically, consumer goods and industrial firms had significantly lower mean days accounts payables compared to consumer services and technology firms, while consumer goods industries had significantly higher mean days accounts receivables compared to the other industries. In addition, it appears that companies took on 
average 154 days to sell their inventory (inventory holding period), whereas no significant differences existed between the four industry sectors, in terms of inventory holding period $(\mathrm{p}=0.686>0.05)$.

The results in Table 1 show that both in the total sample, as well as in the consumer services and technology industries independently, companies receive payments for their sales prior to making payments to creditors (mean days accounts receivables lower than mean days accounts payables). The benefit for these companies is that they can pay their creditors in time, have low financing costs, they can effectively ramp up production to the maximum of consumer demand and have enough capital to reinvest for improvement of corporate value. On the other hand, companies in consumer goods and industrials showed the opposite. In companies where days accounts receivables exceed days accounts payables, limited cash flow and liquidity problems will start taking effect. When companies do not receive payment for their sales, they will seek external sources of financing, which usually involve short-term loans from banks and overdrafts that consequently raise the financing costs. Especially these days in Cyprus loans are very difficult to obtain, due to the general depression in the economy. In general, it is desirable for companies to minimize the difference between days accounts receivables and days accounts payables, especially if it positive.

Regarding the control variables, the mean firm size, as measured by the natural logarithm of sales, was $€ 16.2 \mathrm{~m}$ with a standard deviation of $€ 1.4 \mathrm{~m}$. Significant differences existed between industries $(\mathrm{p}=0.002)$, where the smallest firms were in the technology sector and the largest in industrials. The mean debt ratio of the sample was $26.6 \%$ which represents a good proportion of total liabilities to total assets, while no significant differences existed between industries $(\mathrm{p}=0.134)$. The fixed financial asset ratio had a mean of $8.5 \%$ illustrating that in the companies of our sample only $8.5 \%$ of total assets are represented by fixed financial assets (i.e. investments in subsidiaries and other long-term cash equivalents). Significant differences existed between industries $(p<0.001)$, where technology firms had a significantly higher mean fixed financial asset ratio, compared to all other industries. Finally, the mean GDP growth for the period 2004-2008 was 4.2\% with a standard deviation of $0.5 \%$, depicting the quite stable growth in the economy during that period.

\subsection{Effect of the Cash Conversion Cycle on Profitability}

Pooled OLS regression was used to examine if the cash conversion cycle significantly affects profitability when adjusting for the effect of the control variables. Regarding the examination of the industry effect, the three industry sectors with the largest number of firms, namely consumer goods, industrials, and consumer services, were taken into consideration in all the regression analyses. Table 2 presents the results from pooled OLS regression for the effect of the cash conversion cycle on profitability.

Table-2. Regression results for the effect of the Cash Conversion Cycle on Gross Operating Profit.

\begin{tabular}{|c|c|c|c|c|c|c|c|c|}
\hline \multirow[t]{2}{*}{ Variable } & \multicolumn{2}{|c|}{$\begin{array}{l}\text { All industries } \\
\qquad(\mathrm{N}=300)\end{array}$} & \multicolumn{2}{|c|}{$\begin{array}{l}\text { Consumer goods } \\
\qquad(N=60)\end{array}$} & \multicolumn{2}{|c|}{$\begin{array}{c}\text { Industrials } \\
\quad(\mathbf{N}=\mathbf{8 0})\end{array}$} & \multicolumn{2}{|c|}{$\begin{array}{c}\text { Consumer services } \\
(\mathrm{N}=145)\end{array}$} \\
\hline & Beta & p-value & Beta & p-value & Beta & p-value & Beta & p-value \\
\hline $\mathrm{CCC}$ & -0.082 & 0.173 & 0.264 & $0.048 *$ & -0.558 & $<0.001^{* *}$ & -0.068 & 0.451 \\
\hline Debt & -0.060 & 0.402 & -0.298 & $0.001^{* *} *$ & 0.547 & $0.009 * *$ & -0.355 & $<0.001 * *$ \\
\hline FFA & -0.108 & 0.135 & -0.517 & $<0.001^{* *}$ & -0.281 & 0.170 & -0.036 & 0.682 \\
\hline Size & 0.136 & $0.020^{*}$ & 0.810 & $<0.001 * *$ & 0.351 & 0.727 & 0.136 & 0.106 \\
\hline GDPgr & 0.004 & 0.946 & 0.036 & 0.662 & 0.039 & 0.692 & -0.005 & 0.949 \\
\hline Industry & -0.147 & $0.012^{*}$ & & & & & & \\
\hline R-square & \multicolumn{2}{|c|}{0.071} & \multicolumn{2}{|c|}{0.799} & \multicolumn{2}{|c|}{0.296} & \multicolumn{2}{|c|}{0.129} \\
\hline
\end{tabular}

The results in Table 2 show that when all companies were considered as a merged sample, then the cash conversion cycle did not have a significant effect on profitability $(\mathrm{p}=0.173)$. However, the industry appeared to play a significant role $(p-v a l u e=0.012)$ and thus its effect was further investigated, by examining the three industries with the largest number of firms in the sample independently. It was then shown that CCC had a positive effect on 
the profitability of companies in the consumer goods sector, whereas it had a negative relation with the profitability of companies in the industrials sector. The negative relation shows that for companies in industrials the shorter the period between production and sale, the larger the firm's profitability. Such companies may use the inflow of cash to pay its liabilities on time, avoiding possible penalties from delays, as well as invest in other projects that would result in further profits and additional cash inflows. A longer cash conversion cycle may decrease the firm's profitability, due to reduced liquidity that could increase the firm's risk. On the other hand, for companies in consumer goods, the positive relation between the cash conversion cycle and profitability suggested that an extension of the cash conversion cycle can lead to increased sales and higher profits.

Regarding the control variables, only firm size had an effect on the profitability of the total sample of companies. However, when the industry sectors were examined separately, the debt ratio had a negative effect on consumer goods and consumer services firms, as opposed to a positive effect on industrials. The profitability of firms in the consumer goods industry was additionally affected by the fixed financial asset ratio (negative) as well as the firm size (positive).

\subsection{Effect of the Components of the Cash Conversion Cycle on Profitability}

Profitability was regressed on all the components of the cash conversion cycle, namely days accounts receivables, days accounts payable and the inventory holding period while adjusting for the effect of the control variables. Table 3 shows the regression results.

Table-3. Regression results for the simultaneous effect of all the components of the Cash Conversion Cycle on Gross Operating Profit.

\begin{tabular}{|c|c|c|c|c|c|c|c|c|}
\hline \multirow[t]{2}{*}{ Variable } & \multicolumn{2}{|c|}{$\begin{array}{l}\text { All industries } \\
\quad(\mathrm{N}=300)\end{array}$} & \multicolumn{2}{|c|}{$\begin{array}{c}\text { Consumer goods } \\
\qquad(\mathrm{N}=60)\end{array}$} & \multicolumn{2}{|c|}{$\begin{array}{l}\text { Industrials } \\
\quad(\mathbf{N}=\mathbf{8 0})\end{array}$} & \multicolumn{2}{|c|}{$\begin{array}{c}\text { Consumer services } \\
(\mathrm{N}=145)\end{array}$} \\
\hline & Beta & $\mathrm{p}$-value & Beta & $\mathrm{p}$-value & Beta & p-value & Beta & p-value \\
\hline $\mathrm{AP}$ & 0.023 & 0.693 & -0.237 & $0.003 * *$ & 0.476 & $0.005 * *$ & 0.105 & 0.236 \\
\hline $\mathrm{AR}$ & -0.228 & $<0.001 * *$ & 0.239 & $0.047 *$ & -0.467 & $<0.001^{* *}$ & -0.093 & 0.284 \\
\hline INV & 0.095 & 0.116 & -0.106 & 0.261 & -0.620 & $<0.001^{* *} *$ & 0.183 & $0.043^{*}$ \\
\hline Debt & -0.102 & 0.157 & -0.406 & $<0.001^{* * *}$ & 0.383 & 0.097 & -0.360 & $<0.001^{* *}$ \\
\hline FFA & -0.057 & 0.425 & -0.437 & $<0.001^{* * *}$ & -0.252 & 0.222 & 0.000 & 0.995 \\
\hline Size & 0.136 & $0.025^{*}$ & 0.703 & $<0.001 * *$ & 0.018 & 0.861 & O.199 & $0.029 *$ \\
\hline GDPgr & 0.003 & 0.956 & 0.011 & 0.885 & 0.035 & 0.722 & -0.011 & 0.890 \\
\hline Industry & -0.147 & $0.012^{*}$ & & & & & & \\
\hline R-square & \multicolumn{2}{|c|}{0.123} & \multicolumn{2}{|c|}{0.713} & \multicolumn{2}{|c|}{0.320} & \multicolumn{2}{|c|}{0.178} \\
\hline
\end{tabular}

In the total sample of all companies, the only working capital component that was significant for profitability was days accounts receivables, with a highly negative effect $(\mathrm{p}<0.001)$, indicating that for profitability to increase, days accounts receivables should be kept at a minimum.

Industry differences appeared to exist $(\mathrm{p}=0.012)$, and therefore the major industries of the sample were examined separately, for further investigation of the industry effect. The results for individual industries showed that Days accounts receivables, similar to the results of the merged sample, had a significant negative effect on the profitability of companies in industrials. However, "accounts receivables" had a positive effect on the profitability of companies in the consumer goods industry (beta=0.239), indicating that for such companies, an increase in days accounts receivables is associated with higher profitability. The negative relationship between accounts receivables and firms' profitability for industrials suggests that less profitable firms should pursue a decrease of their accounts receivables in an attempt to reduce their cash gap, while the opposite policy should be implemented for firms in the consumer goods industry. The positive effect of both "accounts receivables" and cash conversion cycle on the profitability of consumer goods firms, actually agrees with the intuitive fact that a generous trade credit policy would result to a longer cash conversion cycle, which in turn would increase profitability. Finally, a non-significant 
effect of accounts receivables was found for consumer services, showing that for this industry the frequency of payment collection does not make a difference.

Days accounts payables did not appear to have a significant effect on profitability when all firms were merged together. However, industry effects were apparent for this component, as well. A significant negative relationship existed for the consumer goods industry, as opposed to a significant positive relation for industrials. The nonsignificant effect in the overall sample was also present in consumer services, showing that it does not make any difference in the profitability of the consumer services industry if suppliers are paid earlier. A positive relationship (e.g. as shown for industrials), suggests that delaying payment to creditors can increase profitability. It could imply that profitable firms take more days to pay their bill, withholding their payment to their creditors to take advantage of the cash available for their working capital needs (Mathuva, 2010). Thereby, the firm can invest these additional funds in short term assets to increase profits. On the other hand, the inverse relation (e.g. for consumer goods), could be explained in that by delaying payment to creditors, a company could miss out on discount given for early payment of purchases, thus increasing its costs, or could result in loss of good suppliers and it could send the signal that the company is inefficient or in trouble (Deloof, 2003; Raheman and Nasr, 2007; Gill et al., 2010).

Interestingly enough, the profitability of companies in industrials was affected by all the components. More specifically, "days accounts payables" had a positive effect, while both days accounts receivables and inventory holding period had a negative effect. Inventory holding period did not have an effect when all the companies were considered together in the merged sample, but when industries were isolated it had an effect on industrials (negative) as well as consumer services (positive coefficient). The negative effect of both accounts receivables and inventory holding period for industrials shows that managers in this sector could create value for their shareholders by reducing both these components to a reasonable minimum. In addition, the negative effect could be explained in that a long period of inventory holding could increase operational costs in the industrial sector due to tied-in capital and increased warehousing and insurance expenses. Since a sudden drop in sales accompanied with mismanagement of inventory will lead to tying up excess capital at the expense of profitable operations, the purpose of inventory management should be to minimize these costs without causing disruption in the production (Bhattacharya, 2003). It should also be noted that the inventory holding period was the only working capital component that significantly affected the consumer services industry. The positive relation that was found shows that by holding extra inventory a company can reduce its supply costs, reduce any possible loss of sales caused by interruptions in the availability of inventory, be protected from price fluctuations brought by extrinsic factors or adverse macroeconomic movements, reduce the risk of stock-outs and of subsequent loss of customers, and eventually increase sales (García-Teruel and Martinez-Solano, 2007; Gill et al., 2010; Mathuva, 2010). The contradictory results found in the present study among industry sectors suggest that managers should carefully decide on the amount of inventory to keep tied in, since keeping too much or too little can cause adverse effects on profitability.

Regarding the control variables, only "firm size" had an effect in the merged sample (positive). Firm size similarly had a positive effect for industrials and consumer services. This shows that larger firms are associated with higher levels of profitability, enjoying the benefits of economies of scale. As an organisation increases in size and gains power, it can take advantage of lower costs, since suppliers may offer better prices with larger orders, have fewer transactions and therefore lower transaction costs, and gain more customers due to higher order capacity (Johnson et al., 2008). It is interesting that some of the key variables in the study did not have a significant effect beyond the controlling effect of the firm size for some industries. Although debt ratio did not have a significant effect in the merged sample, it had a negative effect both in consumer goods and consumer services. A negative effect of debt ratio was similarly found in previous studies (Bagchi and Khamrui, 2012). "Fixed financial assets ratio" had a significant negative effect only in the sample of consumer goods firms $(\beta=-0.437, p<0.001)$, while GDP growth, used for the purpose of controlling for macroeconomic changes in the Cyprus economic environment, was not found to be significantly related to profitability. This result was contrary to the expected outcome that 
profitability would increase under beneficial economic circumstances, which was found in some previous studies (Mathuva, 2010).

Overall, the best model fit was for the model of the consumer goods industry, with an R-square higher than $70 \%$ (almost $80 \%$ in Table 2 and $71 \%$ in Table 3 ). It should also be noted that no endogeneity problems existed in the analyses, in other words, no causality issues existed between the dependent and independent variables.

\section{CONCLUSION AND PRACTICAL IMPLICATIONS}

The present study contributes to the empirical evidence regarding the effect of working capital management on profitability. It can provide lessons from a pre-crisis period, serving as a reference on how to manage working capital components during the current post-crisis years.

The findings show differentiation in the results of the total sample compared to the various industry sectors, which stresses that decision making on working capital policies should take into consideration the industry the firm belongs to and should be generalized. Overall the cash conversion cycle and its components have an effect on profitability, but the sign and level of significance vary according to industry: they are either negative or positive or non-significant for the same working capital component among sectors. If the analysis had been limited only to the merged sample of firms, which is the usual approach in most articles, then the results would have been misleading and would have missed out on the additional evidence regarding the differences existing between the various industry sectors. The findings of the study provide practical implications, suggesting that managers should carefully outweigh costs and benefits prior to any decision regarding working capital investment and need to aim for the optimal level of the cash conversion cycle and its components. In economies like Cyprus, where product differentiation is very difficult due to the low population as opposed to a large number of companies, trade credit policies are an important criterion to customers when it is time to select between various suppliers. Most firms operating within Cyprus are SMEs and encounter problems on borrowing in the long term capital markets and greatly use vendor financing as a means to finance their working capital. At the same time, they need to consider the particular characteristics of the industry they belong to, in order to boost the profitability of their company: it is essential that working capital management policies vary according to the industry sector.

Funding: This study received no specific financial support.

Competing Interests: The author declares that there are no conflicts of interests regarding the publication of this paper.

Contributors/Acknowledgement: The author would like to thank Ms. Irene Charalambous for her assistance with data collection.

\section{REFERENCES}

Abuzayed, B., 2012. Working capital management and firms' performance in emerging markets: The case of Jordan. International Journal of Managerial Finance, 8(2): 155-179.Available https://doi.org/10.1108/17439131211216620.

Bagchi, B. and B. Khamrui, 2012. Relationship between working capital management and profitability: A study of selected FMCG companies in India. Business and Economics Journal, 2012(60): 1-11.

Bernstein, L.A. and J.J. Wild, 1998. Financial statement analysis, theory, application and interpretation. 6th Edn., Boston, US: Irwin/Mc Graw Hill.

Berry, A. and R. Jarvis, 2006. Accounting in a business context andover. UK: Cengage Learning EMEA.

Bhattacharya, H., 2003. Working capital management, strategies and techniques. New Delhi: Prentice Hall.

Bieniasz, A. and Z. Gołaś, 2011. The influence of working capital management on the food industry enterprises profitability. Contemporary Economics, 5(4): 68-81.Available at: https://doi.org/10.5709/ce.1897-9254.29.

Cyprus Stock Exchange, 2011. Information and list: Cyprus stock exchange. Available from http://www.cse.com.cy/gr/

[Accessed January 9, 2016]. 
Deloof, M., 2003. Does working capital management affect profitability of Belgian firms?. Journal of Business Finance \& Accounting, 30(3-4): 573-588.Available at: https://doi.org/10.1111/1468-5957.00008.

Dong, H.P. and J.-T. Su, 2010. The relationship between working capital management and profitability: A Vietnam case. International Research Journal of Finance and Economics, 2010(49): 59-67.

Eda, O. and S. Mehmet, 2009. Relationship between efficiency level of working capital management and return on total assets in ISE. International Journal of Business and Management, 4(10): 109-114.Available at: https://doi.org/10.5539/ijbm.v4n10p109.

Eljelly, A.M., 2004. Liquidity-profitability tradeoff: An empirical investigation in an emerging market. International Journal of Commerce and Management, 14(2): 48-61.Available at: https://doi.org/10.1 108/10569210480000179.

García-Teruel, P.J. and P. Martinez-Solano, 2007. Effects of working capital management on SME profitability. International Journal of Managerial Finance, 3(2): 164-177.Available at: https://doi.org/10.1 108/17439130710738718.

Gill, A., N. Biger and N. Mathur, 2010. The relationship between working capital management and profitability: Evidence from the United States. Business and Economics Journal, 2010(10): 1-9.

Hardouvelis, G. and I. Gkionis, 2016. A decade long economic crisis: Cyprus versus Greece. Cyprus Economic Policy Review, $10(2): 3-40$.

IMF, 2014. Report for selected countries and subjects. World Economic Outlook Database April 2014. Available from http://www.imf.org/external/index.htm [Accessed June 29, 2017].

International Monetary Fund, 2001. Report for selected countries and subjects. World Economic Outlook Database May 2001. Available from http://www.imf.org/external/index.htm [Accessed May 17, 2017].

Johnson, G., K. Scholes and R. Whittington, 2008. Exploring corporate strategy. 8th Edn., Essex, England: Pearson Education Limited.

Kieschnick, R., M. Laplante and R. Moussawi, 2013. Working capital management and shareholders' wealth. Review of Finance, 17(5): 1827-1852.Available at: https://doi.org/10.1093/rof/rfso43.

Lazaridis, I. and D. Tryfonidis, 2006. Relationship between working capital management and profitability of listed companies in the athens stock exchange. Journal of Financial Management \& Analysis, 19(1): 26-35.

Mathuva, D.M., 2010. The influence of working capital management components on corporate profitability: A survey on Kenyan listed firms. Research Journal of Business Management, 4(1): 1-11.

Ministry of Finance, 2011. Stability programme of the Republic of Cyprus 2010-2014, Ministry of Finance, Republic of Cyprus, April, $2011 . \quad$ Available from http://www.mof.gov.cy/mof/mof.nsf/All/C8B39814FFE61438C225788D002499F8/\$file/Stability\%20Programme\% 202010-2014.pdf? OpenElement [Accessed December 11, 2017].

Ministry of Labour and Social Insurance, 2008. Employment in cyprus-2008, Ministry of Labour and Social Insurance, Republic of Cyprus, Press and Information Office. [Accessed December 11, 2017].

MoF, 2004. Convergence programme of the Republic of Cyprus 2004-2008, Ministry of Finance, Republic of Cyprus, December 2004. Available from http://www.mof.gov.cy/mof/MOF.nsf/CDE52469F5710E59C2257552003FADFA/\$file/Gonvergence\%20Program me\%202004-2008.pdf [Accessed September 27, 2017].

Mohamad, N.E.A.B. and N.B.M. Saad, 2010. Working capital management: The effect of market valuation and profitability in Malaysia. International Journal of Business and Management, 5(11): 140-147.Available at: https://doi.org/10.5539/ijbm.v5n11p140.

Muscettola, M., 2014. Cash conversion cycle and firm's profitability: An empirical analysis on a sample of 4,226 manufacturing SMEs of Italy. International Journal of Business and Management, 9(5): 25-35.Available at: https://doi.org/10.5539/ijbm.v9n5p25.

Narware, P., 2008. The institute of cost and works accountants of India. Available from www.icwai.org/icwai/knowledgebank/fm46.pdf [Accessed July 20, 2017]. 
Obeidat, M.I. and A. Jawabri, 2016. The impact of working capital management on the profitability of construction equipment firms: Evidence from listed construction equipment firms in Abu Dhabi stock exchange. Journal of Accounting and Finance, 16(8): 135-147.

Oruc, E. and M. Sen, 2009. Relationship between efficiency level of working capital management and return on total assets in Ise. International Journal of Business and Management, 4(10): 109-114.Available at: https://doi.org/10.5539/ijbm.v4n10p109.

Padachi, K., 2006. Trends in working capital management and its impact on firms' performance: An analysis of Mauritian small manufacturing firms. International Review of Business Research Papers, 2(2): 45-58.

Porta, R.L., F. Lopez-de-Silanes, A. Shleifer and R.W. Vishny, 1998. Law and finance. Journal of Political Economy, 106(6): $1113-1155$.

Raheman, A. and M. Nasr, 2007. Working capital management and profitability-case of Pakistani firms. International Review of Business Research Papers, 3(1): 279-300.

Ramachandran, A. and M. Janakiraman, 2009. The relationship between working capital management efficiency and EBIT. Managing Global Transitions, 7(1): 61-74.

Republic of Cyprus Ministry of Finance Statistical Service, 2003-2008. National accounts: Statistical service of the Republic of Cyprus. Available from http://www.mof.gov.cy/mof/cystat/statistics.nsf [Accessed August 24, 2017].

Sharma, A. and S. Kumar, 2011. Effect of working capital management on firm profitability: Empirical evidence from India. Global Business Review, 12(1): 159-173.Available at: https://doi.org/10.1177/097215091001200110.

Tsangari, H., 2010. Emerging markets investment opportunities: Cypriot investors and Russian mutual funds. International Journal of Business and Emerging Markets, 3(1): 89-106.Available at: https://doi.org/10.1504/ijbem.2011.037687.

Wasiuzzaman, S., 2015. Working capital and firm value in an emerging market. International Journal of Managerial Finance, 11(1): 60-79.Available at: https://doi.org/10.1 108/ijmf-01-2013-0016.

World Bank, 2001. Country and lending groups. Available from http://www.worldbank.org/ [Accessed September 11, 2013].

Zariyawati, M.A., M.N. Annuar, H. Taufiq and R.A.S. Abdul, 2009. Working capital management and corporate performance: Case of Malaysia. Journal of Modern Accounting and Auditing, 5(11): 47-54.

Views and opinions expressed in this article are the views and opinions of the author(s), International Journal of Business, Economics and Management shall not be responsible or answerable for any loss, damage or liability etc. caused in relation to/arising out of the use of the content. 